\title{
Physico-chemical and microbiological characterization of the ground water across the city Bareilly (U.P.), India
}

\author{
D. R. K hanna, Shivom Singh, Neetu Saxena, R. Bhutiani*, Gagan M atta and Dipali B hasker \\ Kulkarni
}

Department of Zoology and Environmental Science, Gurukula Kangri University, Haridwar -249404 (Uttarakhand), INDIA *Corresponding author. E-mail: rbhutiani@gmail.com

\begin{abstract}
The drinking water quality (underground water) of Bareilly city has been assessed by estimating physicochemical parameters and calculating Water Quality Index (WQI). Water Quality Index plays an important role in interpreting the information on water quality. The WQI of different sites shows that drinking water is of good quality. The correlation between different parameters was also estimated. During course of study the average value of physico-chemical parameters studied were observed as temperature $20.17^{\circ} \mathrm{C}$, turbidity $2.17 \mathrm{NTU}, \mathrm{pH} 8.13$, electrical conductivity $1360 \mathrm{mmhos} / \mathrm{cm}$, total dissolved solids $1218.9 \mathrm{mg} / \mathrm{l}$, total hardness $515.0 \mathrm{mg} / \mathrm{l}$ chlorides $106.34 \mathrm{mg} / \mathrm{l}$, alkalinity 342.15 , fluorides $0.44 \mathrm{mg} / \mathrm{l}$, sulphates $84.68 \mathrm{mg} / \mathrm{l}$, nitrates $22.83 \mathrm{mg} / \mathrm{l}, \mathrm{DO} 2.44 \mathrm{mg} / \mathrm{l}$, BOD $1.26 \mathrm{mg} / \mathrm{l}$. While average MPN were observed as 5.66 and average WQI as 21.48 .
\end{abstract}

Keywords: Drinking underground water, WQI, Correlation coefficient, Ground water quality

\section{INTRODUCTION}

Water is the most essential commodity for human consumption. Various physico- chemical parameters like $\mathrm{pH}$, hardness, $\mathrm{DO}, \mathrm{Ca}, \mathrm{Cl}^{-}, \mathrm{F}^{-}$, TDS, alkalinity etc. have a significant role in determining the potability of drinking water(WHO, 1971). Water served to consumers should be free from disease carrying bacteria, colourless, sparkling, tasteless, having DO, free from poisonous material and excessive amount of mineral and organic matter.

In cities, a large section of the population uses water from surface sources and ground water for human consumption. Underground water (water from deep borings and wells) generally contains no turbidity but more mineral salts, free $\mathrm{CO}_{2}, \mathrm{Ca}$ and $\mathrm{Mg}$ salts. Ground water contamination is generally irreversible i.e. once it is contaminated, it is difficult to restore the original quality of the acquifer. Hazardous substance, fertilizers, organic compounds, heavy metal and sewage discharges can seep into ground water from municipal sanitary landfills as well as from hazardous landfills, mining \& agricultural operations, hotels, hospitals etc. These hazardous substances, if disposed off improperly, can eventually contaminate ground water (Akanpo and Igboekwe, 2011). Therefore, it is necessary to assess the quality of underground water used for drinking purposes. In the present study, underground drinking water quality of Bareilly city has been evaluated during winter season by estimating various physico-chemical as Temperature, turbidity, $\mathrm{pH}$, electric conductivity, total dissolved solids, total hardness, chlorides, alkalinity, fluorides, sulphates, nitrates, dissolved oxygen and biochemical oxygen demand and microbiological parameter MPN.

\section{MATERIALS AND METHODS}

Study area: The study area of Bareilly city lies between $28^{\circ} 1^{\prime}-28^{\circ} 54^{\prime} \mathrm{N}$ and $78^{\circ} 58^{\prime}-74^{\circ} 47^{\prime} \mathrm{E}$, covering an area of approximate 1578 sq. miles. The city has a population of about one million. A number of industries such as WIMCO, IFFCO, Coca Cola industry, Katha factory and many ancillary units are present within $20 \mathrm{~km}$ radius of Bareilly. The treated and untreated contaminated effluent from these industries is discharged onto the ground which is absorbed by the soil and thus reaches the ground water table and contaminate it. Nine sampling stations were selected with in the radius of about $10 \mathrm{~km}$ from the center of the city to cover the entire city.

Sampling: The samples were collected in 5 litre dark nonreactive plastic containers, which were thoroughly washed thrice with the water to be analysed. The water quality parameters studied were colour, taste, odour, temperature, turbidity, $\mathrm{pH}, \mathrm{EC}$, TDS, total hardness, chloride, alkalinity, fluoride, sulphate, nitrate, DO, BOD and total coliforms.

The $\mathrm{pH}, \mathrm{EC}$ and $\mathrm{DO}$ were determined within 6 hours of bringing water samples to the laboratory. BOD was measured by incubating the water samples at $20^{\circ} \mathrm{C}$ for five days in the dark. All the parameters were determined as per the standard methods of analysis of water (APHA, 2005).

Water Q uality I ndex (W Q I): WQI was estimated according to the formula (Mahuya et al., 2003) as given below. 
$\mathrm{WQI}=\operatorname{Antilog}\left(\sum \mathrm{W}_{\mathrm{n}} \log \mathrm{q}_{\mathrm{n}}\right)$

Where, $\mathrm{W}_{\mathrm{n}}=$ weight of the parameter in the sample $=K / \mathrm{S}_{\mathrm{n}}$ $\mathrm{K}=$ constant $=1 /\left(1 / \mathrm{S}_{1}+1 / \mathrm{S}_{2}+1 / \mathrm{S}_{3} \ldots \ldots \ldots \ldots+1 / \mathrm{S}_{\mathrm{n}}\right)$

$\mathrm{S}_{\mathrm{n}}=$ standard values for different water quality parameter. $\mathrm{q}_{\mathrm{n}}=$ water quality rating $=100\left(\mathrm{~V}_{\mathrm{n}}-\mathrm{V}_{\mathrm{i}}\right) /\left(\mathrm{S}_{\mathrm{n}}-\mathrm{V}_{\mathrm{i}}\right)$

$\mathrm{V}_{\mathrm{n}}=$ observed value, $\mathrm{V}_{\mathrm{i}}=$ ideal value $=7.0$ for $\mathrm{pH}$, 14.6 for DO, 0 for other parameters.

The water quality of different sites has been rated according to the WQI as given below-

\begin{tabular}{ll}
\hline WQI & Water quality $\bar{r}$ ating \\
\hline $0-25$ & Excellent \\
$26-50$ & Good \\
$51-75$ & Poor \\
$76-100$ & Very poor \\
$>100$ & Unfit for drinking purpose \\
\hline
\end{tabular}

Correlation between differ ent water quality par ameters: The relationship of one water quality parameter with another parameter in the samples of the water analyzed was determined by regression analysis by determining correlation coefficient ' $r$ '.

\section{RESULTS AND DISCUSSION}

The results of various physico-chemical parameters like Temperature, turbidity, $\mathrm{pH}$, electric conductivity, total dissolved solids, total hardness, chlorides, alkalinity, fluorides, sulphates, nitrates, dissolved oxygen and biochemical oxygen demand and microbiological parameter MPN are presented in Table 1.

The appearance of all the tested samples of ground water was clear. They did not have odour and taste. The temperature ranged between $19.4^{\circ} \mathrm{C}$ to $21^{\circ} \mathrm{C}$. All the samples showed very low values of turbidity, ranging from 1.36-3.44 NTU, which were below the permissible limit of 5 NTU prescribed by WHO. The study showed that the $\mathrm{pH}$ of the water samples was in the mild alkaline range of $7.76-8.64$ (within the permissible limits) indicating the presence of very weak basic salts. The conductivity of water ranged from 790- $1920 \mu \mathrm{mho} / \mathrm{cm}$ However the prescribed limit is $1000 \mu \mathrm{mho} / \mathrm{cm}$ as given by WHO for drinking water. The higher values suggested the presence of higher amount of dissolved inorganic substances in ionized form. The TDS in water comprises inorganic salts and small amount of organic matter. The TDS values varied from 700-2496 mg/l. Water with higher solid content indicated that ground water is of inferior potability and may induce an unfavourable physiological reaction in the transient consumer as indicated by Jameel (1998). The desirable limit of TDS for drinking water is $500 \mathrm{mg} / \mathrm{l}$. The total hardness ranged between $307-786.6 \mathrm{mg} / \mathrm{l}$. and was higher than the prescribed standard value $(500 \mathrm{mg} /$ 1). Increase in value pertains to the excess presence of the salts of $\mathrm{Ca}, \mathrm{Mg}$ and Fe. Chlorides, which have been associated with pollution as an index were found in the range of 48.11-181.31 mg/l. The concentration of chloride in the present observations was within the higher range of desirable limit of WHO $(250 \mathrm{mg} / \mathrm{l})$. The phenolphthalein alkalinity was found to be absent in all the samples analyzed and the methyl orange alkalinity varied from $261.2-671 \mathrm{mg} / \mathrm{l}$. This indicated the absence of hydroxyl alkalinity and the presence of carbonate and bicarbonates. However, the values of all the sampling sites were quite higher than the desirable limits $(120 \mathrm{mg} / \mathrm{l})$. The higher value indicates the eutrophic nature of the water. In case of toxic element such as fluoride, ISI has given the desirable limit of $0.6-1.2 \mathrm{mg} / \mathrm{l}$ while WHO has prescribed the limit below $1.5 \mathrm{mg} / \mathrm{l}$. The fluoride content of all the sampling sites ranged between $0.38-0.61 \mathrm{mg} / \mathrm{l}$, which were below the recommended limits. Sulphate content ranged from $62.8-113.6 \mathrm{mg} / \mathrm{l}$, whereas the permissible limit for sulphates is $200 \mathrm{mg} / \mathrm{l}$. The level of nitrates in the ground water ranged between $6.4-90.2 \mathrm{mg} / \mathrm{l}$. Nitrate concentration more than the recommended value $(45 \mathrm{mg} / \mathrm{l})$ was observed on only one site i.e site V (Izat Nagar) than the recommended value. The amount of DO ranged between 2.1 to $2.7 \mathrm{mg} / \mathrm{l}$ in water of all nine sampling stations and was less in comparison to minimum DO recommended by WHO. The lower amount of DO in ground water may be due to the fact that an iron pipe is being used for fitting the hand pumps to supply ground water and both mechanical and chemical processes involved may lead to maximum utilization of $\mathrm{O}_{2}$ and iron leading to formation of iron oxide. The BOD ranged between 0.6-2.1 mg/l and was observed to be within the permissible limit prescribed by WHO. The total coliforms count of all the sampling sites has been found to be in the range of 2-22 MPN per $100 \mathrm{ml}$ i.e. within the prescribed limit of WHO (10 MPN/ $100 \mathrm{ml}$ ). At site SV i.e. (Izatnagar) high total coliform counts were recorded.

W QI: A WQI may be defined as a rating reflecting the composite influence of the overall quality of a number of quality characteristics or water quality parameters (Yazdandoost and Katdare, 2000). The WQI of the nine sampling sites ranged between 17.98 - 26.12 (Table 1) indicating that the ground water of the city is very good for drinking purpose.

Cor relation between water quality parameters: The water quality is usually measured by taking the physical, chemical and biological parameters. But the numbers of such parameters are so high that sometimes it is not possible to specify the quality of water. So it is useful to find the correlation among the various parameters, which will give a rough indication of the quality of water (Mishra et al., 2003). The correlation coefficient ' $r$ ' between different parameters has been calculated as shown in Table 2.

A positive correlation was observed between turbidity 


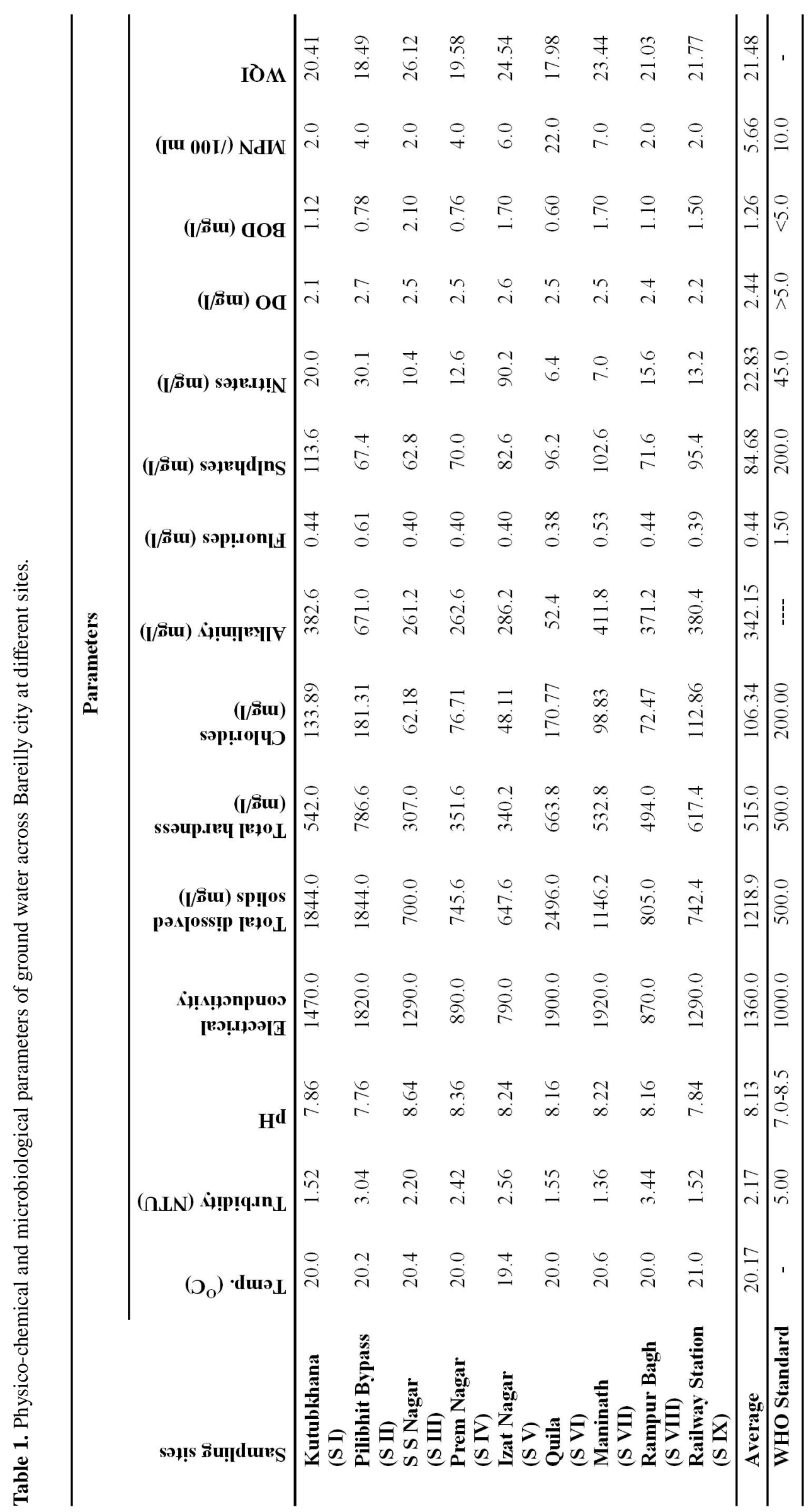


Table 2. Correlation coefficient ' $r$ ' between different water quality parameters.

\begin{tabular}{|c|c|c|c|c|c|c|c|c|c|c|c|c|c|}
\hline & Temp & Turb & $\mathrm{pH}$ & $\mathrm{EC}$ & TDS & $\mathrm{TH}$ & $\mathrm{Cl}^{-}$ & Alk & $F$ & $\mathrm{SO}_{4}^{--}$ & $\mathrm{NO}_{3}^{--}$ & DO & $\mathrm{BOD}$ \\
\hline Turb & -0.44 & & & & & & & & & & & & \\
\hline $\mathrm{pH}$ & -0.18 & 0.06 & & & & & & & & & & & \\
\hline EC & 0.41 & -0.51 & -0.33 & & & & & & & & & & \\
\hline TDS & -0.11 & -0.29 & -0.45 & 0.75 & & & & & & & & & \\
\hline TH & 0.32 & -0.10 & -0.82 & 0.71 & 0.71 & & & & & & & & \\
\hline $\mathrm{Cl}^{-}$ & 0.20 & -0.23 & -0.68 & 0.79 & 0.89 & 0.92 & & & & & & & \\
\hline Alk & 0.25 & 0.36 & -0.57 & 0.16 & -0.07 & 0.43 & 0.24 & & & & & & \\
\hline $\mathrm{F}$ & 0.15 & 0.25 & -0.44 & 0.52 & 0.26 & 0.56 & 0.45 & 0.85 & & & & & \\
\hline $\mathrm{SO}_{4}^{--}$ & 0.16 & -0.79 & -0.44 & 0.41 & 0.42 & 0.29 & 0.32 & -0.15 & -0.09 & & & & \\
\hline $\mathrm{NO}_{3}^{--}$ & -0.66 & 0.33 & -0.04 & -0.46 & -0.26 & -0.27 & -0.34 & 0.10 & -0.03 & -0.11 & & & \\
\hline DO & -0.34 & 0.49 & 0.32 & 0.09 & 0.00 & -0.01 & -0.01 & 0.12 & 0.40 & -0.64 & 0.33 & & \\
\hline BOD & 0.26 & -0.18 & 0.45 & -0.19 & -0.64 & -0.55 & -0.65 & 0.01 & -0.14 & -0.04 & 0.22 & -0.07 & \\
\hline MPN & -0.21 & -0.34 & 0.07 & 0.49 & 0.67 & 0.31 & 0.46 & -0.61 & -0.19 & 0.27 & -0.11 & 0.27 & -0.43 \\
\hline
\end{tabular}

and $\mathrm{pH}(0.06)$, turbidity and fluorides $(0.025)$ turbidity and nitrates (0.33), turbidity and dissolved oxygen $(0.49)$, $\mathrm{pH}$ and dissolved oxygen (0.32), $\mathrm{pH}$ and biochemical oxygen demand (0.45), electrical conductivity and total dissolved solids (0.75), electrical conductivity and total hardness (0.71), electrical conductivity and chlorides $(0.79)$, electrical conductivity and fluorides (0.52), electrical conductivity and sulphates (0.41), TDS and total hardness (0.71), TDS and chlorides (0.89), TDS and fluorides (0.26), Total hardness and chlorides (0.92), total hardness and alkalinity ( 0.43$)$, total hardness and fluorides (0.56), total hardness and sulphates (0.29), chlorides and alkalinity (0.24), chlorides and fluorides (0.45), chlorides and sulphates (0.32), alkalinity and fluorides (0.85), alkalinity and DO (0.12), fluorides and DO (0.04), Nitrates and BOD (0.22). While negative relationship was found between turbidity and electrical conductivity (-0.51), turbidity and TDS (-0.29), turbidity and total hardness ($0.10)$, turbidity and chlorides $(-0.23)$, turbidity and alkalinity (-0.24), turbidity and sulphates (-0.78), turbidity and BOD (-0.18). A negative correlation of $\mathrm{pH}$ with all the parameters except DO and BOD was found during course of study. Electrical conductivity was found negatively correlated with alkalinity (-0.16), nitrates $(-0.46)$, DO ($0.02)$ and BOD (-0.19).TDS was found negatively correlated with BOD (-0.64). Total hardness was found negatively correlated with nitrates $(-0.27)$, DO (-0.01) and BOD (-0.55). Chlorides was found negatively correlated with nitrates (-0.34) and BOD (-0.65). Alkalinity was found negatively correlated with sulphates $(-0.15)$ and MPN (0.61). Fluorides were found negatively correlated with sulphates (-0.09), nitrates (-0.03) and BOD ($0.14)$.Sulphates were found negatively correlated with nitrates (-0.11), DO (-0.64) and BOD (-0.65). Negative correlation was found between DO and $\mathrm{BOD}(-0.006)$.

\section{Conclusion}

From the above study it may be concluded that the drinking water quality of Bareilly city is very good for drinking purpose but the increase in number of MPN at one or two site is alarming and measures should be taken to mitigate such type of problems.

\section{ACKNOW LEDGEMENTS}

The authors are heartily thankful to Dr. D. K. Saxena, Head, PGD Environmental Management, Bareilly College Bareilly for his help and providing necessary facilities.

\section{REFERENCES}

Akankpo,O. and Igboekwe, M.U. (2011). Monitoring ground water contamination using surface electrical resistivity and geochemical methods. Journal of Water Resource and Protection, 3 (5):318-324

APHA, AWWA and WPCF (2005). Standard methods for the examination of water and wastewater. $18^{\text {th }}$ Edition, Greenberg, A.E., Clesceri, L.S. and Trusell, R.R. (Eds.). American Public Health Association, Washington, D.C.

Jameel, A. (1998). Physico- Chemical studies in Vyakondan channel water of river Cauvery. J. of Pollution Research, 17(2): 111-114.

Mahuya Das, Gupta, Adak and Purohit, K.M. (2003). Assessment of the water quality in Rajgangpur industrial complex - Part I: Physico-chemical parameters \& Water Quality Index. J. of Pollution Research, 22 (1): 133-138.

Mishra, P.C., Pradhan ,K.C. and Patel, R.K. (2003). Quality of water for drinking \& agriculture in \& around mines in Keanjhar District, Orissa. Indian J . of E nviron. H ealth, 45 (3): 213-220.

WHO (1971). In: International Standard for Drinking Water, $3^{\text {rd }}$ ed. World Health Organisation, Geneva.

Yazdandoost, M.Y. and Katdare, M.S. (2000). Water Quality Index of major rivers in Pune. J. of Industrial Pollution Control, 16 (2): 231-238. 